Article

\title{
Bioguided Isolation of Active Compounds from Rhamnus alaternus against Methicillin-Resistant Staphylococcus aureus (MRSA) and Panton-Valentine Leucocidin Positive Strains (MSSA-PVL)
}

\author{
Ikrame Zeouk ${ }^{1,2, *}$, Wessal Ouedrhiri ${ }^{3}$, Ines Sifaoui ${ }^{1,4,5}$, Isabel L. Bazzocchi ${ }^{6}$, José E. Piñero ${ }^{1,4,5, *(D)}$, \\ Ignacio A. Jiménez ${ }^{6}{ }^{(D)}$, Jacob Lorenzo-Morales ${ }^{1,4,5, *}$ and Khadija Bekhti ${ }^{2}$
}

check for

updates

Citation: Zeouk, I.; Ouedrhiri, W.; Sifaoui, I.; Bazzocchi, I.L.; Piñero, J.E.; Jiménez, I.A.; Lorenzo-Morales, J.; Bekhti, K. Bioguided Isolation of Active Compounds from Rhamnus alaternus against Methicillin-Resistant Staphylococcus aureus (MRSA) and Panton-Valentine Leucocidin Positive Strains (MSSA-PVL). Molecules 2021, 26, 4352. https://doi.org/10.3390/ molecules26144352

Academic Editor: Andrei I. Khlebnikov

Received: 18 June 2021

Accepted: 15 July 2021

Published: 19 July 2021

Publisher's Note: MDPI stays neutral with regard to jurisdictional claims in published maps and institutional affiliations.

Copyright: (C) 2021 by the authors Licensee MDPI, Basel, Switzerland. This article is an open access article distributed under the terms and conditions of the Creative Commons Attribution (CC BY) license (https:// creativecommons.org/licenses/by/ $4.0 /)$.
1 Instituto Universitario De Enfermedades Tropicales y Salud Pública de Canarias, Universidad de la Laguna Avda. Astrofísico Fco. Sánchez, S/N, 38203 La Laguna, Spain; isifaoui@ull.edu.es

2 Laboratory of Microbial Biotechnology and Bioactive Molecules, Department of Biology, Faculty of Sciences and Techniques, Sidi Mohamed Ben Abdellah University, Fez 2202, Morocco; bekhti.bki4@gmail.com

3 Laboratory of Engineering, Electrochemistry, Modeling and Environment, Department of Chemistry, Faculty of Science, Sidi Mohamed Ben Abdellah University, Fez 2202, Morocco; wessal.ouedrhiri@gmail.com

4 Departamento de Obstetricia, Ginecología, Pediatría, Medicina Preventiva y Salud Pública, Toxicología, Medicina Legal y Forense y Parasitología, Universidad de la Laguna, 38203 La Laguna, Spain

5 Red de Investigación Colaborativa en Enfermedades Tropicales (RICET), Instituto de Salud Carlos III, 28029 Madrid, Spain

6 Departamento de Química Orgánica, Instituto Universitario de Bio-Orgánica Antonio González, Universidad de La Laguna, Avenida Astrofísico Francisco Sánchez 2, 38206 La Laguna, Spain; ilopez@ull.edu.es (I.L.B.); ignadiaz@ull.edu.es (I.A.J.)

* Correspondence: alu0101298412@ull.edu.es (I.Z.); jpinero@ull.edu.es (J.E.P.); jmlorenz@ull.edu.es (J.L.-M.); Tel.: +212-621-290-377 (I.Z.); +349-22-316-502 (J.E.P.); +349-22-318-402 (J.L.-M.)

Abstract: Despite intensified efforts to develop an effective antibiotic, S. aureus is still a major cause of mortality and morbidity worldwide. The multidrug resistance of bacteria has considerably increased the difficulties of scientific research and the concomitant emergence of resistance is to be expected. In this study we have investigated the in vitro activity of 15 ethanol extracts prepared from Moroccan medicinal plants traditionally used for treatment of skin infections. Among the tested species I. viscosa, C. oxyacantha, $R$. tinctorum, $A$. herba alba, and B. hispanica showed moderate anti-staphylococcal activity. However, R. alaternus showed promising growth-inhibitory effects against specific pathogenic bacteria especially methicillin-susceptible Staphylococcus aureus Panton-Valentine leucocidin positive (MSSAPVL) and methicillin-resistant $S$. aureus (MRSA). The bioguided fractionation of this plant using successive chromatographic separations followed by nuclear magnetic resonance (NMR) and mass spectrometry (MS) including EIMS and HREIMS analysis yielded the emodin (1) and kaempferol (2). Emodin being the most active with MICs ranging between 15.62 and $1.95 \mu \mathrm{g} / \mathrm{mL}$ and showing higher activity against the tested strains in comparison with the crude extract, its mechanism of action and the structure-activity relationship were interestingly discussed. The active compound has not displayed toxicity toward murine macrophage cells. The results obtained in the current study support the traditional uses of R. alaternus and suggest that this species could be a good source for the development of new anti-staphylococcal agents.

Keywords: ethnobotany; bioguided fractionation; MRSA; MSSA-PVL; anti-staphylococcal activity; Rhamnus alaternus; emodin

\section{Introduction}

According to the $\mathrm{WHO}, 50,000$ persons around the world are dying every day because of infectious diseases. In the World Health Report, more than 17 million deaths out of a 
total of 52 million were due to infectious diseases [1]. Among many of these disorders, Staphylococcus aureus (S. aureus) is the main responsible pathogenic bacteria with a large clinical spectrum [2]. Within this species there are toxigenic variants such as those expressing Panton-Valentine Leucocidin (PVL) or those expressing Staphylococcal Toxic Shock Toxin (STST). Indeed, PVL is known worldwide for its potential role in virulence and for its involvement in invasive infections. Although only $5 \%$ of $S$. aureus strains produce PVL (Sa-PVL), it is a widely studied toxin. Currently, Duployez et al. [3] have reported a fatal case of a young adult with COVID-19; the complication of viral infection has been linked to necrotizing pneumonia induced by S. aureus producing PVL. Therefore, these toxigenic strains make $S$. aureus infections more dangerous requiring specific clinical treatment $[4,5]$. However, despite the abundance of numerous classes of antibiotics, the emergence of resistant strains is increasing. S. aureus has developed multi-drug resistance toward different antibiotics, especially methicillin (MRSA). MRSA strains include healthcare-associated MRSA (HA-MRSA) and community-associated MRSA (CA-MRSA) aspects which may be an increased risk of spreading the $S$. aureus infections [6] ranging from skin to other invasive diseases such as pneumonia [7], meningitis [8], sepsis [9], osteomyelitis [10], and infective endocarditis [11]. The newest antibiotic on the market (linezolid (Zyvox)) was introduced to the North American market in 2000 [12]. Since 2001, cases of linezolid-resistant MRSA were reported $[13,14]$. To this end, it becomes necessary to search for new safe and efficient anti-staphylococcal agents. Higher plants have been widely described as a rich library for the identification of new active compounds. Rhamnus alaternus belonging to the Rhamnaceae family is a promising resource of phytochemicals, it is a perennial dioecious shrub and an important species of the Mediterranean area widely used in folk medicine [15]. Previous phytochemical analysis has shown that the Rhamnus genus is rich in flavonols such as kaempferol, rhamnetin, and rhamnocitrin [16]. Other investigations have revealed the presence of anthocyanins in $R$. alaternus berries in addition to anthraquinones such as emodin [17-19]. Furthermore, several studies have already explored the biological activities of this plant highlighting numerous pharmacological properties such as antihyperlipidemic, antigenotoxic, and antioxidant effects [20-22]. However, to the best of our knowledge, no in-depth bioguided fractionation of this plant has been conducted against pathogenic bacteria and especially MRSA and Sa-PVL. In the present work, we describe a bioguided fractionation of $R$. alaternus ethanolic extract leading to the isolation and characterization of anthraquinones and flavonoids, we also report the compound which is most likely be involved in the antibacterial activity.

\section{Materials and Methods}

\subsection{General Procedure}

All solvents used were of analytical grade from Sigma-Aldrich. Silicagel $60 \mathrm{~F}_{254}$ (Merck -Darmstadt, Germany) plates $(20 \times 20 \mathrm{~cm})$ supported on aluminum sheet were used for thin-layer chromatography (TLC) separations. Silicagel 60 (Fluka-chemie GmbH) for column chromatography was obtained from Sigma-Aldrich. For the purification procedure, Silica gel 60 (particle size 15-40 and 63-200 $\mu \mathrm{m}$, Macherey-Nagel) was used for column chromatography (CC), while silica gel 60 F254 was used for analytical TLC. The developed TLC plates were visualized by UV light and then spraying with $\mathrm{HOAc}-\mathrm{H}_{2} \mathrm{SO}_{4}$ $\mathrm{H}_{2} \mathrm{O}$ (80:16:4) system, followed by heating at $100{ }^{\circ} \mathrm{C}$ during 3 min. ${ }^{1} \mathrm{H}$ NMR spectrum was carried out on a Bruker Avance 600 spectrometer, with the pulse sequences given by Bruker. The electron impact mass spectrometry (EIMS) and high-resolution electron ionization mass spectrometry (HREIMS) were measured on an LCT Premier XE Micromass Electrospray Spectrometer.

\subsection{Plant Material and Extraction}

Plants were collected from the Atlas Mountains of Imouzzer region-Morocco in July, 2017 and were identified by Pr EL OUALIDI. J. and Pr IBN TATTOU. M. Each plant part was extracted by $6 \mathrm{~h}$ maceration with ethanol $(96 \%)(1: 10 w / v)$ at room temperature with 
continuous stirring at $500 \mathrm{rpm}$ and then air-dried and ground to a powder. A voucher specimen of the active species was conserved under the reference number "RAB107343" in the Herbarium of the Scientific Institute, Rabat, Morocco.

\subsection{Bacterial Strains}

There are a multitude of Staphylococcus aureus strains, each one has specific characteristics. To this end, it is necessary to link each selected strain to specific effects. The strains selected for the present study are characterized by several properties, considering the community of origin, the antibiogram profile, and the absence or presence of PVL toxin, therefore, four strains were selected: three clinical isolates: $S$. aureus ( $\mathrm{Sa}$ ), $S$. aureus (MRSA348), S. aureus PVL (SaPVL+), and a methicillin-resistant reference strain (MRSA (ATCC29213)). All strains with a verified antibiogram profile (Tables S1 and S2) are resistant to methicillin except for the toxigenic strain ( $\mathrm{SaPVL}+$ ) which is sensitive. The antibiogram profile of the studied strains was identified at the Laboratory of Bacteriology in Fez-Morocco. In addition, these strains are often involved in cutaneous infections and other invasive infectious diseases.

\subsection{Antibacterial Testing}

In the present work, the evaluation of anti-staphylococcal activity was carried out by a combination of diffusion and dilution methods. After evaluating of the sensitivity of the strains toward DMSO, the fifteen ethanolic extracts that were previously dissolved at a concentration of $50 \mathrm{mg} / \mathrm{mL}$ in $2 \%(v / v)$ DMSO were screened against the four strains of $S$. aureus previously described.

\subsubsection{Inoculum's Preparation}

Revivification of bacteria was performed by subculturing the agar plate surface LuriaBertani (LB) and incubated at $37^{\circ} \mathrm{C}$ for 18 to $24 \mathrm{~h}$. The microbial inoculums were obtained from fresh colonies through the direct colony suspension method. Hence, 1 to 2 colonies were suspended in a sterile saline solution $(\mathrm{NaCl} 0.9 \%$ ) and adjusted to $0.5 \mathrm{McF}$ arland scale $\left(10^{8} \mathrm{CFU} / \mathrm{mL}\right)$.

\subsubsection{Agar Well Diffusion Assay}

The preliminary screening of different extracts was carried out using the well diffusion method. The agar surface was inoculated by spreading $1 \mathrm{~mL}$ of the bacterial suspension. A vertical hole of $6 \mathrm{~mm}$ was punched aseptically and a volume of 80 to $100 \mu \mathrm{L}$ of each extract at $50 \mathrm{mg} / \mathrm{mL}$ was introduced into each well. Finally, the plates were incubated for $24 \mathrm{~h}$ at $37^{\circ} \mathrm{C}$.

\subsubsection{Agar Dilution Assay}

Since the tested extracts are colored, they may mask the detection of the microbial growth in the liquid medium. For this reason, the agar dilution method was performed for the MIC determination as described by Balouiri et al. [23] with slight modifications. This method consists of incorporating the extract at varying concentrations into the agar medium before its solidification $\left(50^{\circ} \mathrm{C}\right)$. Thus, different concentrations of the crude extracts were prepared in diluted DMSO, then $1 \mathrm{~mL}$ of each dilution was incorporated into $9 \mathrm{~mL}$ of sterile LB to get a serial two-fold dilutions ranging from 16 to $0.5 \mathrm{mg} / \mathrm{mL}$. The obtained mixture was well shaken and distributed into Petri dishes. After the medium solidification, the agar surface was inoculated by spots of $5 \mu \mathrm{L}$ of the inoculum of $10^{5} \mathrm{CFU} / \mathrm{mL}$. The plates were incubated for $24 \mathrm{~h}$ at $37^{\circ} \mathrm{C}$. A control was performed without extract. 
2.5. Bioguided Fractionation and Purification of Bioactive Compounds from the Leaves Extract of R. alaternus

\subsubsection{Bioautography}

Using different mixtures of organic solvents, a preliminary study of polarity was performed to select the optimal eluent system. After checking up the TLC under UV, the best separation was obtained with a mixture of ethyl acetate: methanol: distillated water (8:1:1). Thus, this mobile phase was used for further experiments including bioautography and chromatographic separations.

The immersion bioautography procedure was performed on Silica gel TLC plates $\mathrm{F}_{254}$. Chromatograms were aseptically cut and placed in $9 \mathrm{~cm} \times 9 \mathrm{~cm}$ sterile square Petri dishes and exposed to UV light for $30 \mathrm{~min}$. The crude extract $(1 \mathrm{mg} / \mathrm{mL})$ was applied to the chromatograms and eluted with the previous mobile phase. The developed TLC plates were dried and coated with $15 \mathrm{~mL}$ of inoculated bacterial medium $\left(10^{6} \mathrm{CFU} / \mathrm{mL}\right)$. After medium solidification, the Petri dishes were incubated at $37^{\circ} \mathrm{C}$ for $24 \mathrm{~h}$. Inhibitory zones were detected under UV light of 365 and $254 \mathrm{~nm}[24,25]$.

\subsubsection{Separation and Isolation of Pure Compounds}

To isolate the active compounds detected by bioautography against the four $S$. aureus strains, $8 \mathrm{~g}$ of the crude extract was dissolved in ethanol and subjected to silica gel column chromatography eluted with ethyl acetate: methanol: distillated water (8:1:1). This afforded forty-six fractions combined into twelve fractions based on the TLC profile and coded from F1 to F12. According to the antibacterial assay, F3 (175.9 mg) and F6 (31.5 mg) were the most active and were further chromatographed on a silica column eluted with a mixture of dichloromethane/acetone $\left(\mathrm{CH}_{2} \mathrm{Cl}_{2} / \mathrm{Me}_{2} \mathrm{CO}\right)$ of increasing polarity. As results, subfraction F3A yielded compound 1 (2.5 mg) while subfraction F6B yielded compound 2 (16.6 mg) [26]. The process of this bioguided fractionation is illustrated in Figure 1.

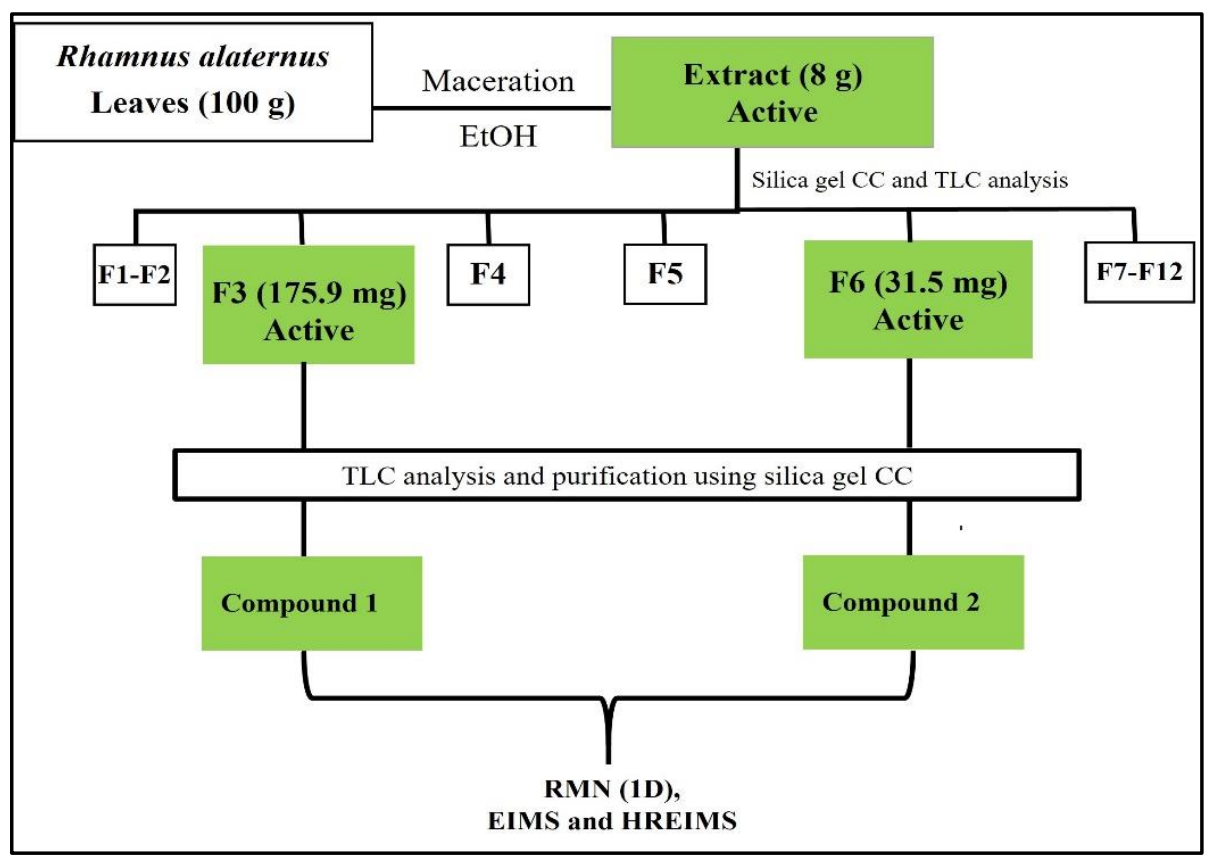

Figure 1. Flowchart of anti-staphylococcal bio-guided fractionation of $R$. alaternus leaves.

\subsubsection{Chemical Structures Characterization}

The various chromatographic purification steps led to the isolation of two pure natural compounds. Samples of these both compounds were dissolved in appropriate deuterated solvents to be analyzed by ${ }^{1} \mathrm{H}$ NMR, EIMS and HREIMS using Bruker Avance 600 spec- 
trometer and an LCT Premier XE Micromass Electrospray Spectrometer. In addition, the obtained spectrums were compared with those previously reported in literature.

\subsection{MIC Determination of Fractions and Pure Compounds}

The MICs of samples obtained from fractionation were determined using the broth microdilution assay using modified 96-well plate following the recommendations published by CLSI for the effective assessment of the antimicrobial potency of natural products (Clinical and Laboratory Standards Institute 2009). In 96-well plates, a $\frac{1}{2}$ dilution range of fractions $(0.78125-500 \mu \mathrm{g} / \mathrm{mL})$ and pure compounds $(0.48827-250 \mu \mathrm{g} / \mathrm{mL})$ was considered. The plates were then inoculated with $50 \mu \mathrm{L}$ of the bacterial suspension adjusted to a density of $5 \times 10^{5} \mathrm{UFC} / \mathrm{mL}$. The growth control contained $50 \mu \mathrm{L}$ of bacterial suspension and $50 \mu \mathrm{L}$ of LB medium, while the negative control contained $100 \mu \mathrm{L}$ of LB medium. The plates were incubated at $37^{\circ} \mathrm{C}$ for $24 \mathrm{~h}$. MIC values were determined after the addition of $10 \mu \mathrm{L}$ of resazurin $0.015 \%(w / v)$ to each well and the plate was re-incubated at $37^{\circ} \mathrm{C}$ for $2 \mathrm{~h}$.

\subsection{Cytotoxicity Assay}

Cytotoxicity test was performed as described by Sifaoui et al. [27], different concentrations of compounds (1) were incubated with the J774A.1 murine macrophage cell line cultured in RPMI medium supplemented with $10 \%$ fetal bovine serum $\left(10^{5}\right.$ cells $\left./ \mathrm{mL}\right)$ for $24 \mathrm{~h}$ at $37^{\circ} \mathrm{C}$ in a $5 \% \mathrm{CO}_{2}$ atmosphere. The viability of the macrophages was determined with the AlamarBlue reagent. Dose response curves were plotted and the $\mathrm{CC}_{50}$ was obtained. The analyses were performed in triplicate.

\section{Results}

\subsection{Preliminary Antistaphylococcal Screening}

In the present work, ethanolic extracts of fifteen plants used in traditional medicine for treatment of infectious diseases such as skin infections, in the Central North of Morocco [28], were evaluated. Leaves of Ammi majus, Artemisia herba alba, Cistus salviifolius, Globularia alypum, Inula viscosa, Lavandula dentata, Nerium oleander, and Rhamnus alaternus; aerial parts of Crataegus oxyacantha and Urtica dioica; roots of Alkanna tintoria, Berberis hispanica, Ephedra altissima and Rubia tinctorum; seeds of Juniperus oxycedrus. The anti-staphylococcal activity of the extracts was determined using the well-diffusion method against clinical isolate and reference strains of $S$. aureus with distinct characteristics and different antibiogram profiles. The diameters of the inhibitory zones were measured (in $\mathrm{mm}$ ). The results obtained showed that among the fifteen ethanolic extracts tested, six extracts were active against the target strains, but with different inhibitory zones. Qualitatively, the ethanolic extracts of $B$. hispanica and $R$. alaternus showed the best activity against all strains, with a more remarkable susceptibility of $S a$ and MRSA (ATCC29213) compared to SaPVL+ and MRSA348 (Table 1).

\subsection{MIC Determination}

The six active extracts were subjected to MIC determination using agar diffusion method. According to the results presented in Table 2, the extracts showed varying degrees of activity against the different strains of $S$. aureus. The extract of $R$. alaternus showed the best inhibitory effect with a MIC of $0.5 \mathrm{mg} / \mathrm{mL}$ against $S a$ and MRSA (ATCC29213), and $1.0 \mathrm{mg} / \mathrm{mL}$ against $\mathrm{SaPVL}+$ and MRSA348. The other extracts showed MICs between 4 and $16 \mathrm{mg} / \mathrm{mL}$. 
Table 1. Inhibition zones of ethanolic extracts of the fifteen plants against S. aureus strains.

\begin{tabular}{ccccc}
\hline \multirow{2}{*}{ Ethanolic Extracts } & \multicolumn{3}{c}{ S. aureus Strains } \\
\cline { 2 - 5 } & SaPVL+ & MRSA348 & Sa & MRSA (ATCC29213) \\
\hline R. alaternus & $14 \pm 1.0$ & $15 \pm 1.0$ & $25.5 \pm 1.5$ & $25 \pm 1.0$ \\
I. viscosa & $12 \pm 1.0$ & $12 \pm 0.81$ & $13.66 \pm 1.88$ & $13 \pm 0.81$ \\
C. oxyacantha & $11 \pm 0.5$ & $14 \pm 0.5$ & $12.33 \pm 1.88$ & $11.66 \pm 1.24$ \\
R. tinctorum & $10 \pm 0.5$ & $20 \pm 0.5$ & $10.33 \pm 0.47$ & $12.5 \pm 0.5$ \\
\hline A. herba alba & $13 \pm 1.88$ & $10 \pm 0.0$ & $14.5 \pm 2.12$ & $13 \pm 0.7$ \\
B. hispanica & $15 \pm 0.0$ & $20 \pm 1.0$ & $26 \pm 1.0$ & $24 \pm 1.0$ \\
E. altissima & NA & NA & NA & NA \\
L. dentata & NA & NA & NA & NA \\
C. salviifolius & NA & NA & NA & NA \\
N. oleander & NA & NA & NA & NA \\
A. tinctoria & NA & NA & NA & NA \\
J. oxycedrus & NA & NA & NA & NA \\
U. dioica & NA & NA & NA & NA \\
G. alypum & NA & NA & NA & NA \\
A. majus & NA & NA & NA & NA \\
\hline
\end{tabular}

Inhibition zones $(\mathrm{mm})$ including the disc diameter $6 \mathrm{~mm}$; NA: not active.

Table 2. Minimum inhibitory concentrations of ethanolic extracts of the six plants selected using the qualitative test against $S$. aureus strains.

\begin{tabular}{ccccc}
\hline \multirow{2}{*}{ Ethanolic Extracts } & \multicolumn{3}{c}{ MIC $(\mathbf{m g} / \mathbf{m L})$} \\
\cline { 2 - 5 } & SaPVL+ & MRSA348 & Sa & MRSA (ATCC 29213) \\
\hline A. herba alba & $>16$ & 16 & 8 & 8 \\
B. hispanica & $>16$ & 16 & 16 & 16 \\
C. oxyacantha & 16 & 16 & 16 & 16 \\
I. viscosa & 8 & 4 & 4 & 4 \\
R. alaternus & 1.0 & 1.0 & 0.5 & 0.5 \\
R. tinctorum & $>16$ & 8 & 16 & 16 \\
\hline
\end{tabular}

The serial dilution ranges from 16 to $0.25 \mathrm{mg} / \mathrm{mL}$; the positive control (spots of $5 \mu \mathrm{L}$ of the bacterial suspension on the agar medium) showed normal growth.

Based on the results of qualitative and quantitative tests, the best anti-staphylococcal effect was obtained by the extract of $R$. alaternus. Therefore, this plant was selected for further assays aimed at isolating and identifying the compounds responsible for this activity.

\subsection{Bioguided Fractionation and Identification of Active Compounds}

To isolate the compounds involved in the promising activity of R. alaternus against $S$. aureus, the ethanolic extract was subjected to a bioguided fractionation-alternating chemical and biological tests, followed by several separations and chromatographic purification steps. As a result, forty-six fractions were collected, combined according to their TLC profiles into twelve fractions (F1-F12) and tested against S. aureus strains. The MIC determination of the fractions obtained was performed using the microdilution method with resazurin as a staphylococcal viability indicator at a concentration ranging from 500 to $0.7812 \mu \mathrm{g} / \mathrm{mL}$. The results obtained are presented in Table 3 . As expected from the preliminary results of the bioautography which showed optimal zones of inhibition, fractions F3 $(175.9 \mathrm{mg})$ and F6 (31.5 mg) were the most active with MICs between 31.5 and $200 \mu \mathrm{g} / \mathrm{mL}$. SaPVL+, MRSA348, and MRSA (ATCC29213) showed the same susceptibility level to both fractions, while $S a$ was the most susceptible to F3 with a MIC of $31.5 \mu \mathrm{g} / \mathrm{mL}$, but the least susceptible to F6 with a MIC of $200 \mu \mathrm{g} / \mathrm{mL}$. 
Table 3. Minimum inhibitory concentrations of R. alaternus fractions against the four strains of $S$. aureus.

\begin{tabular}{ccccc}
\hline Strains & SaPVL+ & MRSA348 & Sa & MRSA (ATCC 29213) \\
\hline R. alaternus & \multicolumn{2}{c}{ MIC $(\boldsymbol{\mu g} / \mathbf{m L})$} \\
\hline Crude extract & 1000 & 1000 & 500 & 500 \\
F1-F2 & NA & NA & NA & NA \\
F3 & 125 & 125 & 31,5 & 125 \\
F4 & NA & NA & NA & NA \\
F5 & DN & DN & DN & DN \\
F6 & 50 & 50 & 200 & 50 \\
F7-F12 & $>1000$ & $>1000$ & $>1000$ & NG \\
Control + & NG & NG & NG & NG \\
Control - & NG & NG & NG & .
\end{tabular}

Based on the results obtained, only the active fractions (F3 and F6) were selected for further purification using other silica gel chromatographic columns leading to the isolation of two pure natural compounds. The sub-fraction of F3 gave compound (1) $(2.5 \mathrm{mg})$, and the purification of $\mathrm{F} 6$ gave compound (2) $(16.6 \mathrm{mg})$.

NMR analyses $\left({ }^{1} \mathrm{H}\right.$ and $\left.{ }^{13} \mathrm{C}\right)$ of these compounds led to the identification of emodin (1) kaempferol (2) (Figure 2). The spectroscopic data from the NMR spectra (Figures S3 and S4) corroborate those previously reported in the literature [29,30]. In addition, mass spectrometry analyses were performed to confirm the structures obtained (Figures S5-S8).

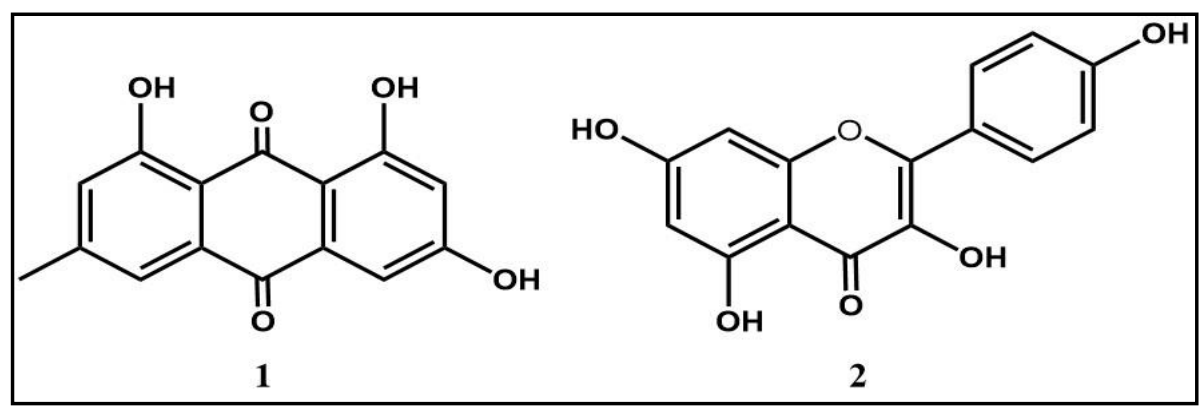

Figure 2. Chemical structures of emodin (1) and kaempferol (2) isolated from the leaves of R. alaternus.

After confirmation of the chemical structures of the two compounds, the determination of MICs and BMCs was performed by the microdilution method still using resazurin as an indicator of staphylococcal viability at a concentration range from $250-0.4882 \mu \mathrm{g} / \mathrm{mL}$. In addition, the cytotoxic profile of the active compound was evaluated using AlamarBlue as an indicator of murine macrophage viability (Table 4).

Table 4. Minimum inhibitory concentrations of pure compounds isolated from R. alaternus fractions against the four strains of $S$. aureus cytotoxicity test and selectivity index against murine macrophages.

\begin{tabular}{|c|c|c|c|c|c|c|c|c|c|}
\hline \multirow{2}{*}{ Compound/Strain } & \multicolumn{2}{|c|}{ SaPVL+ } & \multicolumn{2}{|c|}{ MRSA348 } & \multicolumn{2}{|c|}{$S a$} & \multicolumn{2}{|c|}{ MRSA (ATCC 29213) } & \multirow{2}{*}{$\begin{array}{c}\text { Murin Macrophages } \\
\mathrm{CC}_{50}(\mu \mathrm{g} / \mathrm{mL})\end{array}$} \\
\hline & $\begin{array}{c}\text { MIC } \\
(\mu \mathrm{g} / \mathrm{mL})\end{array}$ & SI & $\begin{array}{c}\text { MIC } \\
(\mu \mathrm{g} / \mathrm{mL})\end{array}$ & SI & $\begin{array}{c}\text { MIC } \\
(\mu \mathrm{g} / \mathrm{mL})\end{array}$ & SI & $\begin{array}{c}\text { MIC } \\
(\mu \mathrm{g} / \mathrm{mL})\end{array}$ & SI & \\
\hline Emodin & 15.63 & $>6.4$ & 15.63 & $>6.4$ & 1.95 & $>51.28$ & 15.63 & $>6.4$ & $>100$ \\
\hline Kaempferol & $>250$ & - & $>250$ & - & $>250$ & - & $>250$ & - & - \\
\hline Control + & NG & & NG & & NG & & NG & & \\
\hline Control - & NG & & NG & & NG & & NG & & \\
\hline
\end{tabular}

Control +: strain and LB medium; control -: strain and 2\% DMSO; NG: normal growth. BMC of emodin $>250 \mu \mathrm{g} / \mathrm{mL}$. MIC: minimum inhibitory concentration. $\mathrm{CC}_{50}$ : cytotoxic concentration that reduces viability of murine macrophages by $50 \%$. SI: $\mathrm{CC}_{50} / \mathrm{MIC}$. 
Based on Table 4, we can note that emodin strongly inhibited the growth of the tested strains with a MIC of $15.63 \mu \mathrm{g} / \mathrm{mL}$ against SaPVL+, MRSA348, and MRSA (ATCC29213), and a much lower MIC against $S a(1.95 \mu \mathrm{g} / \mathrm{mL})$. However, kaempferol was not active at the concentration tested $(>250 \mu \mathrm{g} / \mathrm{mL})$.

\subsection{Cytotoxicity Assay}

The in vitro cytotoxicity of emodin as the active compound was evaluated by calculating the percentage of living macrophage cells regarding different concentrations. Subsequently, the curve obtained allows the calculation of $\mathrm{CC}_{50} \mathrm{~s}$ corresponding to the concentration of the compound for which there is a $50 \%$ reduction in cell viability compared to untreated macrophages. The determination of the $\mathrm{CC}_{50}$ s allows the calculation of the selectivity index. The results showed that emodin was not toxic on the J774A.1 macrophage cell line $\left(\mathrm{CC}_{50}>100 \mu \mathrm{g} / \mathrm{mL}\right)$.

\section{Discussion}

S. aureus is one of the pathogens involved in a wide clinical spectrum. The emergence of multidrug-resistant and toxigenic strains is a serious public health problem. A multitude of studies have confirmed that the rate of infections worldwide is progressively increasing with the rise of drug resistance and that clinical anti-infective treatment of resistant strains has become more difficult [31,32] especially when the infections are caused by methicillinresistant and/or Panton-Valentine leukocidin positive strains. Indeed, MRSA strains were once largely confined to hospitals, health care services, and patients attending these facilities, known as HA-MRSA. Unfortunately, new strains of MRSA, often referred to as community-associated MRSA (CA-MRSA) strains, appear to be rapidly disseminated in the population and infect people with and without hospital exposure [33]. These CA-MRSA strains participate in widespread severe MRSA infections [34,35].

Therefore, a special interest was taken in the search for new compounds of natural origin. In the present work, screening tests on different strains of S. aureus showed that among the fifteen ethanolic extracts prepared from various plant species, the ethanolic extract of $R$. alaternus was the most active against the four target strains of $S$. aureus. We suppose that these results could be explained, on the one hand, by the differences in the permeability of the cell walls to secondary metabolites, and on the other hand, by the differences in the chemical composition of the plants leading to a different mechanism of action. In other words, the extract may contain one or more compounds that are specifically more effective against various strains of $S$. aureus characterized by different pathogenic and resistant profiles. Despite the antibacterial potential of $R$. alaternus in the present study, very limited data are available in the literature regarding its antimicrobial effect, especially the anti-staphylococcal activity. It was reported that evaluation of the antibacterial activity of nine extracts and fractions of the leaves of $R$. alaternus showed that this species exhibits a broad spectrum of antibacterial activity against a wide list of pathogens including a reference strain of S. aureus (ATCC25923). Only ethyl acetate extracts, total flavonoid oligomers, and the ethyl acetate fraction obtained from freezedrying of the aqueous extract showed antibiotic activity against $S$. aureus with MIC values ranging from 70 to $150 \mu \mathrm{g} / \mathrm{mL}$; phytochemical screening of these extracts revealed their richness in flavonoids and phenolic compounds [36]. Kosalec et al. have also evaluated the antimicrobial potential of methanolic bark extracts of four species of Rhamnus genus against several bacteria, dermatophytes, and yeasts. They have demonstrated that the extract of R. alaternus inhibited the growth of $S$. aureus but with a MIC of $2.5 \mathrm{mg} / \mathrm{mL}$ and the analysis of the anthraquinone profile revealed the presence of chrysophanol as the main compound, emodin and physion [37]. Although in these studies the leaves and bark of $R$. alaternus inhibited the growth of $S$. aureus, in both studies the characterization and purification of the bioactive compounds responsible for the activity was not completed and the antibacterial activity was only tested on reference strains which do not really reflect the reality of clinical strains. 
In contrast to antibacterial activities, the literature has focused much more on other previously documented pharmacological properties of $R$. alaternus. These studies have allowed the characterization of a large list of bioactive compounds but especially antioxidants. Purification procedures have highlighted the presence of flavonols such as kaempferol, rhamnetin and rhamnocitrin [16], anthocyanins [17] and anthraquinones such as emodin [18,19]. The identification of the compounds responsible for the anti-staphylococcal activity of $R$. alaternus in this work was performed by a bio-guided fractionation, spectroscopic and spectrometric analysis which confirms the abundance of anthraquinones and flavonoids. Our purification process identified emodin belonging to the anthraquinone family and kaempferol to the group of flavonoids, which agree with the literature. Furthermore, we have shown that emodin is the compound responsible for the antibacterial potential of $R$. alaternus showing a promising activity (MIC up to $1.95 \mu \mathrm{g} / \mathrm{mL}$ ) with a non-toxic concentration toward murine macrophages.

Indeed, emodin is a secondary metabolite with a wide range of biological properties in vitro and in vivo: anticancer, antioxidant, anti-inflammatory, antiviral, antiallergic, antibacterial, etc., [38]. Although our study is the first to report the antibacterial effect of emodin isolated from $R$. alaternus, this compound is well-known for its anti-staphylococcal potential when isolated from other plants. Basu et al. have shown that emodin isolated from Ventilago madraspatana bark was active against S. aureus with an MIC of $90 \mu \mathrm{g} / \mathrm{mL}$ higher than the value reported in our study [39]. Chukwujekwu et al. have reported that emodin isolated from the roots of Cassia occidentalis is the responsible compound for the antimicrobial activity of the ethanolic extract especially against $S$. aureus with a MIC of $3.9 \mu \mathrm{g} / \mathrm{mL}$ highlighting a more interesting effect than the reference antibiotic, neomycin [40]. On the other hand, it was shown that emodin purified from the roots and rhizomes of Rheum officinale affected the thermogenic curves of $S$. aureus growth by improving the antimicrobial effect [41]. Similar effects were noted against MRSA and MSSA. Cao et al. have identified emodin as the active compound in Polygoni cuspidati extract. Among the seven major compounds purified, only emodin showed significant activity against a clinical strain of MRSA while causing morphological alterations of the cell wall [42]. Ji et al. have conducted a proteomic study to compare the effect of emodin on MRSA and MSSA strains. They have demonstrated that after treatment of both strains with emodin, protein expression levels were altered by multiple similar mechanisms of action in MRSA than in MSSA namely induction of pyruvate pathway imbalance, inhibition of protein synthesis, and suppression of DNA synthesis, in addition to membrane alterations [43]. In fact, these mechanisms of the action exerted by emodin have been widely confirmed in the literature [44-46].

By cross-analysis of the biological and phytochemical data, we can hypothesize the chemical nature of the bioactive compound in the present study, the activity and selectivity of emodin toward $S$. aureus strains may be related, for example, to functional groups on the phenyl ring of the compound. These findings were confirmed by the researchers. A structure-activity relationship (SAR) study indicated that the hydroxyl groups and the methyl group in the emodin backbone were crucial for anti-MRSA activity and the presence of an iodine atom or an ethylamine group on the aromatic ring improved the activity with higher selectivity index [47]. Furthermore, another study showed that the structure of emodin was strongly involved in the antimicrobial activity. The substitution at position 2 of emodin was detrimental to the antibacterial activity, while the unsaturation of the substitute was important for the activity. Thus, increasing the aliphatic chain length of the methoxyl group at position 3 increases the lipophilicity of the compound, which increases its ability to integrate the bacterial cell wall, which becomes permeable [48].

Nevertheless, emodin's low solubility, poor bioavailability, and oral absorption limit its development into a pharmaceutical product. Several researchers have conducted in vivo trials on the pharmacokinetics of emodin in order to improve its solubility and oral bioavailability by following different approaches such as inhibition of crystallization, glucurono- 
conjugation, and addition of solubility enhancers such as cyclodextrin A and nanoparticles or combination of emodin with other molecules such as piperine and antibiotics [49-54].

In the present work, we have also shown that kaempferol was not active at the tested concentration, which corroborates the study reported by Falcão-Silva et al. where they have indicated that kaempferol glycoside isolated from Herissantia tiubae did not show relevant activity against $S$. aureus $(\mathrm{MIC}=256 \mu \mathrm{g} / \mathrm{mL}$ ), but rather this compound modulated the activity of antibiotics, which in combination with antibiotics, reduced MIC values by enhancing the putative efflux pump inhibitory effect in the bacteria [55].

Another important point to discuss in the present work is the evaluation of different strains of S. aureus. In fact, we cannot say that methicillin-resistant or multidrug-resistant strains are the only ones involved in invasive infections, but rather they limit the choice of antibiotic therapy. In this context, several studies have compared the involvement of methicillin-susceptible strains (MSSA) and MRSA in different infections. Ding et al. have evaluated whether there was a difference between breast abscesses caused by MRSA and MSSA. They have noted a dominance of MSSA isolates $(N=132)$ over MRSA $(N=39)$, but there was no significant difference in antibiotic use rate, cure rate, and median number of aspirations performed to cure [56]. However, in a prospective study, it was noted that MSSA caused $79 \%$ of infections, while MRSA caused only $21 \%$ concluding that during the study period MSSA was the main cause of invasive S. aureus infections but the classical virulence toxin PVL was rare in these isolates [57]. Furthermore, Sapri et al. have demonstrated that the most virulent genes, such as PVL, were more frequently found in MSSA than in MRSA. Taken together, these data with specific $S$. aureus strains, the authors have suspected an inverse relationship between resistance and virulence in S. aureus [58]. In other words, multidrug-resistant strains tend to harbor fewer virulent genes, while MSSA strains are more virulent but susceptible to antibiotics. This hypothesis was previously confirmed by Cameron et al., exploring available clinical and experimental data, they have shown that many major steps in the evolution of resistance in S. aureus are accompanied by virulence alterations [59]. However, other researchers have reported that increased virulence and the development of antibiotic resistance often occur almost simultaneously, but in complex genetic relationships [60].

\section{Conclusions}

Among the 15 plants selected for the in vitro inhibition of MRSA and MSSA-PVL, $R$. alaternus was the most active. The bioguided fractionation of the extract of this plant yielded emodin as the active compound without inducing toxicity toward murine macrophages. However, further in vivo pharmacological research will be required to fully understand the pharmacokinetics of the active compound, to improve its solubility and to evaluate a possible synergistic interaction with other compounds leading to an effective antistaphylococcal formulation.

\section{Patent}

Results about fraction 5 (Data not shown) have been subjected to a patent.

Supplementary Materials: The following are available online. Table S1: The susceptibility test of S. aureus strains (Sa and MRSA (ATCC 29213)); Table S2: The susceptibility test of S. aureus strains (MRSA348 et SaPVL+); Figure S3: ${ }^{1} \mathrm{H}$ NMR spectrum of emodin (600 MHz, CDCl3); Figure S4: ${ }^{1} \mathrm{H}$ NMR spectrum of kaempferol (600 MHz, C3H6O); Figure S5: EIMS spectrum of emodin; Figure S6: EIMS spectrum of kaempferol; Figure S7: HREIMS spectrum of emodin; Figure S8: HREIMS spectrum of kaempferol.

Author Contributions: I.Z.: data curation, investigation, methodology, writing-original draft. W.O.: data curation, investigation, methodology. I.S.: data curation, investigation. I.L.B.: funding acquisition, supervision. J.E.P.: funding acquisition, supervision. I.A.J.: funding acquisition, supervision, writing-review and editing. J.L.-M.: funding acquisition, supervision, writing-original draft, writing-review and editing. K.B.: supervision, methodology. All authors have read and agreed to the published version of the manuscript. 
Funding: This work was supported by the Fondo Europeo de Desarollo Regional-FEDER [PI18/01380]; the Spanish MINECO co-funded by FEDER [RTI2018-094356-B-C21] and RICET: project of the programme of Redes Temáticas de Investigación Cooperativa, FIS [no. RD16/0027/0001]; the Spanish Ministry of Science, Innovation and Universities, Madrid, Spain; I.Z. was funded by a grant from Vicerrectorado de Internacionalización, Universidad de La Laguna; I.S. was funded by RICET: project of the programme of Redes Temáticas de Investigación Cooperativa. J.L.M. was funded by the Vicerrectorado de Investigación, Transferencia y Campus Santa Cruz y Sur, Universidad de La Laguna.

Institutional Review Board Statement: Not applicable.

Informed Consent Statement: Not applicable.

Data Availability Statement: Data are available within the text and from corresponding authors.

Acknowledgments: We are grateful to Bouchra Oumokhtar from laboratory of Microbiology in Faculty of Medicine and Pharmacy-Fez and Mounyr Balouiri for providing the studied bacterial strains.

Conflicts of Interest: The authors declare no conflict of interest.

\section{References}

1. WHO. The World Health Report 1996_Fighting Disease, Fostering Development; WHO: Geneva, Switzerland, $1997 ;$ Volume 18.

2. Ebani, V.V. Biology and pathogenesis of Staphylococcus infection. Microorganisms 2020, 8, 383. [CrossRef] [PubMed]

3. Duployez, C.; Guern, R.L.; Tinez, C.; Lejeune, A.; Robriquet, L.; Six, S.; Loïez, C.; Wallet, F. Panton-Valentine Leukocidin-Secreting. Emerg. Infect. Dis. 2020, 26, 1939-1941. [CrossRef]

4. Nakaminami, H.; Ozawa, K.; Sasai, N.; Ikeda, M.; Nemoto, O.; Baba, N.; Matsuzaki, Y.; Sawamura, D.; Shimoe, F.; Inaba, Y.; et al. Current status of Panton-Valentine Leukocidin-Positive methicillin-resistant Staphylococcus aureus isolated from patients with skin and soft tissue infections in Japan. J. Dermatol. 2020, 47, 1280-1286. [CrossRef] [PubMed]

5. Petraitiene, B.; Conejo, P.R.; Jankauskaite, L.; Kevalas, R.; Trumpulyte, G.; Snipaitiene, A.; Vitkauskiene, A.; Gurskis, V. Prevalence, clinical expression, invasiveness and outcome of Staphylococcus aureus containing Panton-Valentine leukocidin in children treated in a university hospital of Lithuania. Infect. Dis. 2020, 52, 464-472. [CrossRef] [PubMed]

6. Chow, A.; Htun, H.L.; Hon, P.Y.; Ang, B.; Kanagasabai, K.; Koh, J.; Holden, M.T.G.; Hsu, L.Y. Comparative epidemiology and factors associated with major healthcare-associated methicillin-resistant Staphylococcus aureus clones among interconnected acute-, intermediate- and long-term healthcare facilities in Singapore. Clin. Microbiol. Infect. 2020. [CrossRef]

7. Grousd, J.A.; Rich, H.E.; Alcorn, J.F. Host-Pathogen interactions in gram-positive bacterial pneumonia. Clin. Microbiol. Rev. 2019, 32, 1-22. [CrossRef]

8. Aguilar, J.; Urday-Cornejo, V.; Donabedian, S.; Perri, M.; Tibbetts, R.; Zervos, M. Staphylococcus aureus meningitis case series and literature review. Medicine 2010, 89, 117-125. [CrossRef] [PubMed]

9. Bawazir, Y.M.; Mustafa, M.A. Acute Esophageal Necrosis Associated With Methicillin-Resistant Staphylococcus Aureus Septicemia: A Case Report. Cureus 2020, 12. [CrossRef]

10. Weiss, L.; Lansell, A.; Figueroa, J.; Suchdev, P.S.; Kirpalani, A. Declining prevalence of methicillin-resistant Staphylococcus aureus septic arthritis and osteomyelitis in children: Implications for treatment. Antibiotics 2020, 9, 101. [CrossRef] [PubMed]

11. Selton-Suty, C.; Célard, M.; Le Moing, V.; Doco-Lecompte, T.; Chirouze, C.; Iung, B.; Strady, C.; Revest, M.; Vandenesch, F.; Bouvet, A.; et al. Preeminence of staphylococcus aureus in infective endocarditis: A 1-year population-based survey. Clin. Infect. Dis. 2012, 54, 1230-1239. [CrossRef]

12. Brickner, S.J.; Barbachyn, M.R.; Hutchinson, D.K.; Manninen, P.R. Linezolid (ZYVOX), the first member of a completely new class of antibacterial agents for treatment of serious Gram-positive infections. J. Med. Chem. 2008, 51, 1981-1990. [CrossRef]

13. Tsiodras, S.; Gold, H.S.; Sakoulas, G.; Eliopoulos, G.M.; Wennersten, C.; Venkataraman, L.; Moellering, R.C.; Ferraro, M.J. Linezolid resistance in a clinical isolate of Staphylococcus aureus. Lancet 2001, 358, 207-208. [CrossRef]

14. Rouard, C.; Garnier, F.; Leraut, J.; Lepainteur, M.; Rahajamananav, L.; Languepin, J.; Ploy, M.C.; Bourgeois-Nicolaos, N.; DoucetPopulaire, F. Emergence and within-host genetic evolution of methicillin-resistant staphylococcus aureus resistant to linezolid in a cystic fibrosis patient. Antimicrob. Agents Chemother. 2018, 62, 1-11. [CrossRef] [PubMed]

15. Ammar, R.B.; Kilani, S.; Bouhlel, I.; Ezzi, L.; Skandrani, I.; Boubaker, J.; Sghaier, M.B.; Naffeti, A.; Mahmoud, A.; Chekir-Ghedira, L.; et al. Antiproliferative, antioxidant, and antimutagenic activities of flavonoid-enriched extracts from (Tunisian) Rhamnus alaternus L.: Combination with the phytochemical composition. Drug Chem. Toxicol. 2008, 31, 61-80. [CrossRef] [PubMed]

16. Cuoco, G.; Mathe, C.; Vieillescazes, C. Liquid chromatographic analysis of flavonol compounds in green fruits of three Rhamnus species used in Stil de grain. Microchem. J. 2014, 115, 130-137. [CrossRef]

17. Longo, L.; Vasapollo, G.; Rescio, L. Identification of anthocyanins in Rhamnus alaternus L. berries. J. Agric. Food Chem. 2005, 53, 1723-1727. [CrossRef] [PubMed] 
18. Ammar, R.B.; Miyamoto, T.; Chekir-Ghedira, L.; Ghedira, K.; Lacaille-Dubois, M.A. Isolation and identification of new anthraquinones from Rhamnus alaternus L and evaluation of their free radical scavenging activity. Nat. Prod. Res. 2019, 33, $280-286$. [CrossRef]

19. Izhaki, I.; Tsahar, E.; Paluy, I.; Friedman, J. Within population variation and interrelationships between morphology, nutritional content, and secondary compounds of Rhamnus alaternus fruits. New Phytol. 2002, 156, 217-223. [CrossRef]

20. Bhouri, W.; Sghaier, M.B.; Kilani, S.; Bouhlel, I.; Dijoux-Franca, M.G.; Ghedira, K.; Ghedira, L.C. Evaluation of antioxidant and antigenotoxic activity of two flavonoids from Rhamnus alaternus L. (Rhamnaceae): Kaempferol 3-O- $\beta$-isorhamninoside and rhamnocitrin 3-O- $\beta$-isorhamninoside. Food Chem. Toxicol. 2011, 49, 1167-1173. [CrossRef] [PubMed]

21. Tacherfiout, M.; Petrov, P.D.; Mattonai, M.; Ribechini, E.; Ribot, J.; Bonet, M.L.; Khettal, B. Antihyperlipidemic effect of a Rhamnus alaternus leaf extract in Triton-induced hyperlipidemic rats and human HepG2 cells. Biomed. Pharmacother. 2018, 101, 501-509. [CrossRef]

22. Ammar, R.B.; Bhouri, W.; Sghaier, M.B.; Boubaker, J.; Skandrani, I.; Neffati, A.; Bouhlel, I.; Kilani, S.; Mariotte, A.M.; ChekirGhedira, L.; et al. Antioxidant and free radical-scavenging properties of three flavonoids isolated from the leaves of Rhamnus alaternus L. (Rhamnaceae): A structure-activity relationship study. Food Chem. 2009, 116, 258-264. [CrossRef]

23. Balouiri, M.; Sadiki, M.; Ibnsouda, S.K. Methods for in vitro evaluating antimicrobial activity: A review. J. Pharm. Anal. 2016, 6, 71-79. [CrossRef]

24. Dewanjee, S.; Gangopadhyay, M.; Bhattacharya, N.; Khanra, R.; Dua, T.K. Bioautography and its scope in the field of natural product chemistry. J. Pharm. Anal. 2015, 5, 75-84. [CrossRef]

25. Annuryanti, F.; Isnaeni, I.; Darmawati, A.; Rosyidah, I.; Dwiana, A.N. Method validation of contact and immersion tlcbioautography for determination of streptomycin sulfate in shrimp. Turk. J. Pharm. Sci. 2020, 17, 254-258. [CrossRef] [PubMed]

26. Zeouk, I.; Ouedrhiri, W.; Jiménez, I.A.; Morales, J.L.; Bazzocchi, I.L.; Bekhti, K. Intra-combined antioxidant activity and chemical characterization of three fractions from Rhamnus alaternus extract: Mixture design. Ind. Crop. Prod. 2020, 144, 112054. [CrossRef]

27. Sifaoui, I.; López-Arencibia, A.; Martín-Navarro, C.M.; Reyes-Batlle, M.; Wagner, C.; Chiboub, O.; Mejri, M.; Valladares, B.; Abderrabba, M.; Piñero, J.E.; et al. Programmed cell death in Acanthamoeba castellanii Neff induced by several molecules present in olive leaf extracts. PLOS ONE 2017, 12, 1-12. [CrossRef] [PubMed]

28. Zeouk, I.; Ouali Lalami, A.E.; Bekhti, K. In Vitro Antibacterial Activity of Medicinal Plants in the Central North of Morocco: A Possible Source of Alternative Drugs Against Methicillin-Resistant Staphylococcus Aureus. Asian J. Pharm. Clin. Res. 2019, 12, 285-292. [CrossRef]

29. Mari, S.H.; Varras, P.C.; Atia-Tul-Wahab; Choudhary, I.M.; Siskos, M.G.; Gerothanassis, I.P. Solvent-Dependent structures of natural products based on the combined use of DFT calculations and 1H-NMR chemical shifts. Molecules 2019, $24,2290$. [CrossRef]

30. Demmak, R.G.; Bordage, S.; Bensegueni, A.; Boutaghane, N.; Hennebelle, T.; Mokrani, E.H.; Sahpaz, S. Chemical constituents from solenostemma argel and their cholinesterase inhibitory activity. Nat. Prod. Sci. 2019, 25, 115-121. [CrossRef]

31. Guo, Y.; Song, G.; Sun, M.; Wang, J.; Wang, Y. Prevalence and Therapies of Antibiotic-Resistance in Staphylococcus aureus. Front. Cell. Infect. Microbiol. 2020, 10, 1-11. [CrossRef]

32. Scudiero, O.; Brancaccio, M.; Mennitti, C.; Laneri, S.; Lombardo, B.; De Biasi, M.G.; De Gregorio, E.; Pagliuca, C.; Colicchio, R.; Salvatore, P.; et al. Human defensins: A novel approach in the fight against skin colonizing staphylococcus aureus. Antibiotics 2020, 9, 198. [CrossRef]

33. David, M.Z.; Daum, R.S. Community-Associated methicillin-resistant Staphylococcus aureus: Epidemiology and clinical consequences of an emerging epidemic. Clin. Microbiol. Rev. 2010, 23, 616-687. [CrossRef]

34. Gill, V.C.; Ma, I.; Guo, M.; Gregson, D.B.; Naugler, C.; Church, D.L. Sociodemographic and geospatial associations with community-associated methicillin-resistant Staphylococcus aureus (CA-MRSA) infections in a large Canadian city: An 11 year retrospective study. BMC Public Health 2019, 19, 1-9. [CrossRef] [PubMed]

35. Wang, X.; Towers, S.; Panchanathan, S.; Chowell, G. A Population Based Study of Seasonality of Skin and Soft Tissue Infections: Implications for the Spread of CA-MRSA. PLoS ONE 2013, 8. [CrossRef]

36. Ammar, R.B.; Kilani, S.; Bouhlel, I.; Skandrani, I.; Naffeti, A.; Boubaker, J.; Ben Sghaier, M.; Bhouri, W.; Mahmoud, A.; ChekirGhedira, L.; et al. Antibacterial and cytotoxic activities of extracts from (Tunisian) Rhamnus alaternus (Rhamnaceae). Ann. Microbiol. 2007, 57, 453-460. [CrossRef]

37. Kosalec, I.; Kremer, D.; Locatelli, M.; Epifano, F.; Genovese, S.; Carlucci, G.; Randić, M.; Zovko Končić, M. Anthraquinone profile, antioxidant and antimicrobial activity of bark extracts of Rhamnus alaternus, R. fallax, R. intermedia and R. pumila. Food Chem. 2013, 136, 335-341. [CrossRef]

38. Dong, X.; Fu, J.; Yin, X.; Cao, S.; Li, X.; Lin, L.; Huyiligequi; Ni, J. Emodin: A review of its pharmacology, toxicity and pharmacokinetics. Phyther. Res. 2016, 30, 1207-1218. [CrossRef] [PubMed]

39. Basu, S.; Ghosh, A.; Hazra, B. Evaluation of the antibacterial activity of Ventilago madraspatana Gaertn., Rubia cordifolia Linn., and Lantana camara Linn.: Isolation of emodin and physcion as active antibacterial agents. Phyther. Res. 2005, 19, 888-894. [CrossRef] [PubMed]

40. Chukwujekwu, J.C.; Coombes, P.H.; Mulholland, D.A.; van Staden, J. Emodin, an antibacterial anthraquinone from the roots of Cassia occidentalis. South Afr. J. Bot. 2006, 72, 295-297. [CrossRef] 
41. Yanwen, W.; Wenyuan, G.; Xiaohe, X.; Yi, L. Calorimetric investigation of the effect of hydroxyanthraquinones in Rheum officinale Baill on Staphylococcus aureus growth. Thermochim. Acta 2005, 429, 167-170. [CrossRef]

42. Cao, F.; Peng, W.; Li, X.; Liu, M.; Li, B.; Qin, R.; Jiang, W.; Cen, Y.; Pan, X.; Yan, Z.; et al. Emodin is identified as the active component of ether extracts from Rhizoma Polygoni Cuspidati, for anti-MRSA activity. Can. J. Physiol. Pharmacol. 2015, 93, 1-9. [CrossRef]

43. Ji, X.; Liu, X.; Peng, Y.; Zhan, R.; Xu, H.; Ge, X. Comparative analysis of methicillin-sensitive and resistant Staphylococcus aureus exposed to emodin based on proteomic profiling. Biochem. Biophys. Res. Commun. 2017, 494, 318-324. [CrossRef]

44. Liu, B.; Yuan, B.; Zhang, L.; Mu, W.; Wang, C. ROS/p38/p53/Puma signaling pathway is involved in emodin-induced apoptosis of human colorectal cancer cells. Int. J. Clin. Exp. Med. 2015, 8, 15413-15422.

45. Yan, X.; Gu, S.; Shi, Y.; Cui, X.; Wen, S.; Ge, J. The effect of emodin on Staphylococcus aureus strains in planktonic form and biofilm formation in vitro. Arch. Microbiol. 2017, 199, 1267-1275. [CrossRef] [PubMed]

46. Hou, X.; Wei, W.; Fan, Y.; Zhang, J.; Zhu, N.; Hong, H.; Wang, C. Study on synthesis and bioactivity of biotinylated emodin. Appl. Microbiol. Biotechnol. 2017, 101, 5259-5266. [CrossRef] [PubMed]

47. Chalothorn, T.; Rukachaisirikul, V.; Phongpaichit, S.; Pannara, S.; Tansakul, C. Synthesis and antibacterial activity of emodin and its derivatives against methicillin-resistant Staphylococcus aureus. Tetrahedron Lett. 2019, 60, 151004. [CrossRef]

48. Kemegne, G.A.; Mkounga, P.; Essia Ngang, J.J.; Sado Kamdem, S.L.; Nkengfack, A.E. Antimicrobial structure activity relationship of five anthraquinones of emodine type isolated from Vismia laurentii. BMC Microbiol. 2017, 17, 1-8. [CrossRef]

49. Lee, Y.S.; Kang, O.H.; Choi, J.G.; Oh, Y.C.; Keum, J.H.; Kim, S.B.; Jeong, G.S.; Kim, Y.C.; Shin, D.W.; Kwon, D.Y. Synergistic effect of emodin in combination with ampicillin or oxacillin against methicillin-resistant Staphylococcus aureus. Pharm. Biol. 2010, 48, 1285-1290. [CrossRef] [PubMed]

50. Shi, Y.; Li, H.; Li, J.; Zhi, D.; Zhang, X.; Liu, H.; Wang, H.; Li, H. Development, optimization and evaluation of emodin loaded nanoemulsion prepared by ultrasonic emulsification. J. Drug Deliv. Sci. Technol. 2015, 27, 46-55. [CrossRef]

51. Di, X.; Wang, X.; Liu, Y. Effect of piperine on the bioavailability and pharmacokinetics of emodin in rats. J. Pharm. Biomed. Anal. 2015, 115, 144-149. [CrossRef]

52. Li, H.; Yang, T.; Zhou, H.; Du, J.; Zhu, B.; Sun, Z. Emodin combined with nanosilver inhibited sepsis by anti-inflammatory protection. Front. Pharmacol. 2017, 7. [CrossRef]

53. Ban, E.; An, S.H.; Park, B.; Park, M.; Yoon, N.E.; Jung, B.H.; Kim, A. Improved Solubility and Oral Absorption of EmodinNicotinamide Cocrystal Over Emodin with PVP as a Solubility Enhancer and Crystallization Inhibitor. J. Pharm. Sci. 2020, 109, 3660-3667. [CrossRef]

54. Wang, D.; Sun, M.; Zhang, Y.; Chen, Z.; Zang, S.; Li, G.; Li, G.; Clark, A.R.; Huang, J.; Si, L. Enhanced therapeutic efficacy of a novel colon-specific nanosystem loading emodin on DSS-induced experimental colitis. Phytomedicine 2020, 78, 153293. [CrossRef]

55. Falcão-Silva, V.S.; Silva, D.A.; Souza, M.d.F.V.; Siqueira-Junior, J.P. Modulation of Drug Resistance in Staphylococcus aureus by a Kaempferol Glycoside from Herissantia tiubae (Malvaceae) 1367. Phyther. Res. 2009, 23, 1367-1370. [CrossRef] [PubMed]

56. Ding, S.T.; He, X.P.; Ma, X.J.; Zhang, Y.; Liu, X.X.; Qin, J. Lactational Breast Abscesses Caused by Methicillin-Resistant or Methicillin-Sensitive Staphylococcus aureus Infection and Therapeutic Effect of Ultrasound-Guided Aspiration. Breastfeed. Med. 2020, 15, 471-474. [CrossRef]

57. Crandall, H.; Kapusta, A.; Killpack, J.; Heyrend, C.; Nilsson, K.; Dickey, M.; Daly, J.A.; Ampofo, K.; Pavia, A.T.; Mulvey, M.A.; et al. Clinical and molecular epidemiology of invasive Staphylococcus aureus infection in Utah children; continued dominance of MSSA over MRSA. PLoS ONE 2020, 15, 1-14. [CrossRef]

58. Sapri, H.F.; Sani, N.A.M.; Neoh, H.-M.; Hussin, S. Epidemiological Study on Staphylococcus aureus Isolates Reveals Inverse Relationship between Antibiotic Resistance and Virulence Repertoire. Indian J. Microbiol. 2013, 53, 321-322. [CrossRef] [PubMed]

59. Cameron, D.R.; Howden, B.P.; Peleg, A.Y. The interface between antibiotic resistance and virulence in staphylococcus aureus and its impact upon clinical outcomes. Clin. Infect. Dis. 2011, 53, 576-582. [CrossRef] [PubMed]

60. Schroeder, M.; Brooks, B.D.; Brooks, A.E. The complex relationship between virulence and antibiotic resistance. Genes 2017, 8, 39. [CrossRef] [PubMed] 